\title{
A Learning Quality in Master Program of Educational Administration
}

\author{
Asti Putri Kartiwi ${ }^{1, *}$, Aris Nupan ${ }^{2}$ and Romlan ${ }^{3}$ \\ ${ }^{1}$ Master Program of Educational Administration, University of Bengkulu \\ ${ }^{2}$ Al Qudwah Islamic Junior High School, Musi Rawas District \\ ${ }^{3}$ Education Office of North Musi Rawas District \\ *Corresponding author. Email: astiputri@unib.ac.id
}

\begin{abstract}
The quality of learning has always been an important issue in an educational institution. The quality of learning can be seen from a variety of different points of view because it is a dynamic concept according to the development of the times. In the future, the quality of learning, especially in higher education, is increasingly questioned because of the use of the online learning process. The aim of the research is to describe the quality of learning in the Master's program in Administration of Education, Faculty of Teacher and Educational Sciences, Bengkulu University. A descriptive survey is the research method used. The population of this study was as many as 163 students with a sample of 116 students in the 2nd semester, Semester 3, and Semester 4 students in the Master Study Program in Education Administration. The results of the study are that the quality of learning in the education administration master's program is in the category of both the lowest dimension is the learning process and the lecturer's performance is the high dimension. Advice is given to the master's lecturers.
\end{abstract}

Keywords: Descriptive survey, Educational quality, Higher education, Learning process.

\section{INTRODUCTION}

The development of an increasingly competitive society requires everyone to compete fairly. The improvement of quality education resources must start with a quality component, where there is a learning process in the classroom, resulting in quality human resources. Schools are required to encourage the improvement of the learning process to achieve the required culture of quality [1][2].

Low-quality education at all levels and in all units, especially at the level of higher education, is the main problem facing Indonesian society. Various efforts have been made to improve the quality of national education, such as the preparation of national and regional curriculum content, as well as through training to improve the ability of lecturers. The buying of books and learning tools, the buy and access to educational facilities and infrastructure, and the quality of higher education are often becoming a big problem in developing countries.

However, there is no significant improvement in the different indicators of the quality of education, because there are still educational problems in Indonesia, namely the input and output analysis is not included in policy and implementation of national education. Management at Indonesia's higher education level, therefore, has a responsibility to build its institutions into an institution that excels for everything. To make the school competitive, strong efforts and motivation are needed. It wasn't because of competing in terms of prestige and feeling superior, but still competing to create an education that can benefit learners, the environment of the community, and all levels of education are expected to benefit.

The development of education in the digital age is based on the successful transition of digital systems to the learning process in higher education institutions. This is not easy because the digital-based education system adaptation is accompanied by the development of the human resources that the education process will carry out [3].

The research conducted by Latif et al, put forward factors that contribute to the quality of services in universities include teacher quality, administrative services, knowledge services, activities, continuous improvement, and leadership quality [4]. The fulfillment of these six indicators will be a benchmark for the quality of services in the college.

The quality of education can be seen from various points of view considering the concept of quality or dynamic quality. Institutionally, especially in the college quality can be seen from the accreditation 
owned by the institution [5]. On the other hand, quality can also be seen from how much interest of the community to send their children to the institution [6].

Besides these two things, the standard of education can also be seen by the quality of graduates, how many graduates can be quickly absorbed into the world of work. Internally measuring the quality of education can be from the quality of the learning process carried out in educational institutions [7].

The quality of learning is a condition that describes the effectiveness of learning. Effective learning is learning that facilitates students to actively interact with various learning resources so that learners achieve learning goals effectively and efficiently. To improve the quality of learning lecturers as facilitators should provide the latest information in the efforts of students to develop thinking skills. In particular, a master's program of educational administration students is always required to carry out the learning process independently. Looking for reading materials and recent research examples are important for learners [8].

To improve the quality of learning means that there are efforts made by educational institutions or educators, especially lecturers in realizing the desired level of the learning process [9].

The learning process is said to be successful when there is a restructuring of changes in the cognitive, affective, and psychomotor aspects of students. The change is used as an indication of the implementation of the learning process properly and appropriately. In particular, the key to improving the quality of learning is the interaction between educators and learners. Education will be considered successful if in the process of education there is a science transfer process between educators and learners [10].

As an educational institution that continuously strives to improve the quality of the Master of Education Administration study program, Faculty of Teacher Training and Education Sciences, the University of Bengkulu continues to adapt to all developments in the world of education. One of the focuses of the study program is the improvement of learning quality that involves all resources in the organization.

Since the enactment of social distancing and work from home activities in the even semester of 2019 2020 due to the covid-19 outbreak that hit all regions of Indonesia inevitably all lecture activities and administration face-to-face are limited from the beginning of March to now May 2020. To continue the learning process until the end of the even semester
2019-2020, lecturers as teachers are required to master information technology-based learning media. Changes in the learning process must be adapted immediately to environmental conditions so that education does not run into obstacles [11]. One way to facilitate and solve learning problems is technologybased learning models [12][13].

Technology-based learning imposed by the master of administration study program must consist of an interesting learning process, lecturer's understanding of the content of the material, learning outcomes, and the performance of lecturers [14][15].

Based on the above, researchers want to know how the description of the quality of learning in the master study program of education administration, faculty of teacher training and education sciences, the University of Bengkulu during the covid 19 pandemic.

\section{METHOD}

The research method used in this research is a descriptive survey, descriptive survey is research that uses a questionnaire as a data collection tool and then interpreted by the field of science studied. Quantitative research with a survey model is widely used in researches oriented to respondents' understanding of a condition in an institution. The population in this study were students of semester 2 , semester 3, and semester 4 of the master program of education administration with sampling techniques Stratified simple random sampling that is taking a sample with an average in each cluster respondents [16].

Because the total sample studied number is more than 100 so that the sampling formula is used to represent the entire sample studied. Withdrawal of samples in this study was conducted using a randomized samples technique. Sampling techniques were calculated using the formula of taro Yamane or Slovin as follows.

Description:

$$
\begin{aligned}
& \mathrm{n}=\text { Number of samples } \\
& \mathrm{N}=\text { Population } \\
& \mathrm{e}^{2}=\begin{array}{l}
\text { Precision (set at } 5 \% \text { with confidence } \\
\text { level } 95 \%)
\end{array}
\end{aligned}
$$

So that obtained a sample of 115 people with the following details: 
Table 1. Population and Research Samples

\begin{tabular}{ccccl}
\hline No & Describe & Class & Population & \multicolumn{1}{c}{ Sample } \\
\hline 1 & $2^{\text {nd }}$ semester & class A & 20 student & 14 student \\
2 & $2^{\text {nd }}$ semester & class B & 20 student & 14 student \\
3 & $3^{\text {nd }}$ semester & class A & 10 student & 7 student \\
4 & $3^{\text {nd }}$ semester & class B & 37 student & 26 student \\
5 & $4^{\text {nd }}$ semester & class A & 51 student & 36 student \\
6 & $4^{\text {nd }}$ semester & class B & 25 student & 18 student \\
& Total & & 163 student & 115 student \\
\hline
\end{tabular}

In this study, the principle of categorization of the average response score of respondents was adopted from the book Business Research Methodology by Sugiyono, namely through the maximum score range with a minimum score divided by the number of categories desired [17]. Then the average score of respondents' responses was consulted against the classifier table. In accordance with the number of answer options on the questionnaire submitted, the study continued to use 5 categories to classify the average response score of respondents. The criteria used in the assessment of respondents' average response score are Excellent/Very Good, Good/high, Medium/Fair, Poor/Low, and Not Good/Very Low which are arranged based on the score range as in the following table.

Table 2.

Responden's Mean Score Criteria

\begin{tabular}{|c|c|c|}
\hline No. & Rata-Rata skor & Kriteria \\
\hline 1 & $1,00-1,80$ & Very Low \\
\hline 2 & $1,81-2,60$ & Low \\
\hline 3 & $2,61-3,40$ & Fair \\
\hline 4 & $3,41-4,20$ & Good \\
\hline 5 & $4,21-5,00$ & Very Good \\
\hline
\end{tabular}

\section{RESULTS}

It is known that the quality of learning in the education administration master program is measured in 4 dimensions based on the research results, namely the learning process, understanding of the material, learning outcomes, and output of the lecturer. The study was operated using 27 statement items. An overview of the average score of respondents' answers to each proposed indicator for each dimension as described below.
Table 3.

Description All Responden Respons Table

\begin{tabular}{|c|c|c|c|}
\hline Responden & Dimensi & Rata-Rata & Kategori \\
\hline \multirow[t]{4}{*}{$2^{\text {nd }}$ Semester Student's } & Learning Proses & 4,18 & Good \\
\hline & $\begin{array}{l}\text { Understanding of the } \\
\text { Material }\end{array}$ & 4,37 & Very Good \\
\hline & Learning Output & 4,26 & Very Good \\
\hline & Lecturer Performance & 4,64 & VeryGood \\
\hline \multicolumn{2}{|c|}{ Total Respon $2^{\text {nd }}$ Semester Student } & 4,36 & Very Good \\
\hline $3^{\text {rd }}$ & Learning Proses & 4,43 & Very Good \\
\hline \multirow[t]{3}{*}{ Semester Student's } & $\begin{array}{l}\text { Understanding of the } \\
\text { Material }\end{array}$ & 4,63 & Very Good \\
\hline & Learning Output & 4,40 & Very Good \\
\hline & Lecturer Performance & 4,73 & Very Good \\
\hline \multicolumn{2}{|c|}{ Total Respon $3^{\text {rd }}$ Semester Student } & 4,55 & Very Good \\
\hline \multirow[t]{4}{*}{$4^{\text {th }}$ Semester Student's } & Learning Proses & 2,49 & Low \\
\hline & $\begin{array}{l}\text { Understanding of the } \\
\text { Material }\end{array}$ & 2,65 & fair \\
\hline & Learning Output & 2,57 & Fair \\
\hline & Lecturer Performance & 2,72 & Fair \\
\hline \multicolumn{2}{|c|}{ Total Respon $4^{\text {th }}$ Semester Student } & 2,61 & Fair \\
\hline \multirow[t]{4}{*}{ All Responden } & Learning Proses & 3,70 & Good \\
\hline & $\begin{array}{l}\text { Understanding of the } \\
\text { Material }\end{array}$ & 3,88 & Good \\
\hline & Learning Output & 3,74 & Good \\
\hline & Lecturer Performance & 4,03 & Good \\
\hline \multicolumn{2}{|l|}{ Total } & 3,84 & Good \\
\hline
\end{tabular}

Based on the table above, it is known that the response of 2nd-semester students and 3rd-semester students to the overall dimension of learning quality is in a very good category. Meanwhile, the response of 4th-semester student respondents was in a fair category.

The respondents' responses related to student perceptions in each different generation. Students in semester 2 and semester 3 are still carrying out the learning process so it is very intense to meet with lecturers. The learning process is still going well, the interaction is well built so that it can directly assess the performance of lecturers. While 4th-semester students are students who are writing a thesis so that the interaction of lecturers and students is reduced. Student independence takes precedence because if students are not active in consulting with lecturers then the learning process will not run. Discussions are not well-established and communication is increasingly limited. At the time, face-to-face learning was restricted. However, the regular learning process continues because it is temporarily scheduled for students who are writing a thesis if students are not actively looking for lecturers to discuss then the process of sharing concept and guidance does not go well. This caused the response of 4 th-semester student 
respondents to the quality of learning to be in the category "Fair"

The overall result of the respondent response survey is known that the quality of learning in the Master of Education Administration study program, faculty of education and teacher training, University of Bengkulu is in the "Good" category.

The highest dimension based on respondents' responses is the performance dimension of lecturers. In other words, the lecturer motivation indicators, lecturer communication with students, lecturers' commitment to the quality of learning, and the application of innovations in learning have been met well.

\section{DISCUSSION}

It is known from the research results through the survey method that the quality of learning in the Master of Education administration study program is in a good category. The dimensions fulfilled include process learning, understanding the material, learning output, and lecturer performance.

Based on the analysis of researchers that respondents' responses in student's 2nd and 3rdsemester students on average responded to the overall dimensions in the category was very good while the responses of 4th-semester student respondents were in fair categories. The dimension that is considered lacking by the 4 th-semester student respondents is the learning process. Learning strategies or learning approaches in 4th-semester students are considered less good. 4th-semester students are students who are writing a thesis so that their interaction with lecturers is less intense during this online learning period. Refraction of communication or learning during thesis guidance is felt easier in offline mode due to direct interaction compared to online mode.

The Learning Process can be interpreted as every systematic and deliberate effort to create educational interaction activities between two parties, namely between learners "learning citizens" and educators "learning resources" who conduct teaching activities [18].

Something that can be said to be of quality can be seen from two points of view namely consumers and service providers. The educational process can be said to be successful if students feel the results of the learning process. Motivation and interaction are interconnected as stated by Schiefele that motivation and the contextual learning process are interconnected [19]. Poor interaction and poor communication process in the learning process directly will have an impact on the quality of learning [20].

The performance of lecturers contributes very highly to improving the quality of learning in higher education. Lecturers are considered as facilitators, especially in master's programs. Students in master's programs are given a more independent learning process so that the role of lecturers as facilitators is very large. Lecturers' skills in mastering cutting-edge technology and teaching materials are also one of the important factors. In the research developed by Sharko et al. [21], it is known that the high performance of lecturers has a great influence on the quality of learning at the University of Albania. Based on instruments distributed to students online known lecturers' knowledge, the most updated syllabuses and texts used for teaching, better class management, and course organizations play a role in improving performance and impacting the quality of learning.

The obstacles in online learning applied are the ability of lecturers and students who lack mastery of technology so that it is related to the online learning process carried out.Negative student perception of online learning will hinder the adaptation process to the learning process. Negative perceptions arise because online learning is perceived by the lack of interaction between lecturers and students. The inhibiting indicator is a poor signal in some areas. Besides online learning is carried out by students while doing other work so that it feels less focused.

The lack of commitment from students and lecturers for online learning is still felt to be lacking. The learning process will run optimally when the learning process is regularly planned, but when students join the thesis writing process in semester 4 , the contact between lecturers and students will be decreased. Discussions on the completion of the study were also delayed by the failure to find the right time for online debate.

\section{CONCLUSION}

This research concludes that the overall results of respondent's responses to the quality in the master of education administration study program are in the category of "Good". 


\section{SUGGESTION}

Researchers advise the managers of master's courses in education administration, faculty of teacher training, and educational sciences of Bengkulu University to create quality online learning programs. Quality measured by student satisfaction with the entire learning process, learning outcomes, material mastery, and lecturer performance.

\section{REFERENCES}

[1] Hadullo, Kennedy; Oboko, Robert; Omwenga, Elijah. Factors affecting asynchronous elearning quality in developing countries university settings. International Journal of Education and Development using ICT, 2018, 14.1.

[2] Musfah, J. Analisis kebijakan pendidikan. Prenada Media. 2016

[3] Lin, M. H., \& Chen, H. G. A study of the effects of digital learning on learning motivation and learning outcome. Eurasia Journal of Mathematics, Science and Technology Education, 2017. 13(7), 35533564.

[4] Latif, K. F., Latif, I., Farooq Sahibzada, U., \& Ullah, M. (2019). In search of quality: measuring higher education service quality (HiEduQual). Total Quality Management \& Business Excellence, 30(7-8), 768-791.

[5] Regnier, Kate, et al. Accreditation for learning and change: quality and improvement as the outcome.Journal of Continuing Education in the Health Professions, 2005, 25.3: 174-182. https://doi.org/10.1002/chp.26's

[6] Bransford, John; Vye, Nancy; Bateman, Helen. Creating high-quality learning environments: Guidelines from research on how people learn. In: The Knowledge Economy and Postsecondary Education: Report of Workshop. 2002. p. 159-198.

[7] Zaborova, E. N.; Glazkova, I. G.; Markova, T. L. Distance learning: Students' perspective. Sociological Studies, 2017, 2.2: 131-139.

[8] Zhang, Weiyuan; Cheng, Yau Ling. Quality assurance in e-learning: PDPP evaluation model and its application. International Review of Research in Open and Distributed Learning, 2012, 13.3: 66-82.
[9] Ismaniati, Christina. The use of information and communication technology in improving the quality of learning. Yogyakarta: Yogyakarta State University, 2010.

[10] Biggs, John, Tang, \& Catherine. Teaching for Quality Learning At University. London: McGraw-Hill, 2011.

[11] Stracke, Christian M.; ShamarinaHeidenreich, T. The need to change education towards open learning. The need for change in education: Openness as default, 2015, 11-23.

[12] Jung, Insung. The dimensions of e-learning quality: from the learner's perspective. Educational Tech. Research and Development, 2011, 59, 445-464.

[13] Lim, Cher Ping; Wang, Libing. Blended learning for quality higher education: selected case studies on implementation from AsiaPacific. UNESCO Bangkok Office, 2016.

[14] Schiefele, Ulrich. Interest, learning, and motivation. Educational psychologist, 1991, 26.3-4: 299-323. DOI: https://doi.org/10.1080/ 00461520.1991 .9653136

[15] Riduwan. Rumus dan Data dalam Aplikasi Statistika. Bandung: Alfabeta. 2007.

[16] Hoy, W. K., \& Adams, C.M. (2015). Quantitative research in education: A primer. Sage Publications.

[17] Sudjana, Nana. Assessment of teaching and learning outcomes. Bandung: Teen Rosdakarya, 2009.

[18] Sugiyono. Metode Penelitian Bisnis. Bandung: Alfabeta, 2005.

[19] Suryana, S. Permasalahan mutu pendidikan dalam perspektif pembangunan pendidikan. Edukasi, 2017. 2(1).

[20] Cardoso, Sónia; Rosa, Maria J.; Stensaker, Bjørn. Why is quality in higher education not achieved? The view of academics. Assessment \& evaluation in higher education, 2016, 41.6: 950-965.

[21] Sharko, A. D., Sharko, G., Demi, B., \&Baholli, I. (2015). Development of EUETLPE web application (UET online lecturer performance evaluation system). Journal of educational and social research, 5(2), 93-93. 